\title{
PERBEDAAN KADAR INTERLEUKIN-1B CAIRAN SULKUS GINGIVA PADA AKTIVASI PERANTI ORTODONTI LEPASAN
}

\author{
Kornialia* \\ *Departemen Ortodonsia, Fakultas Kedokteran Gigi Universitas Baiturrahmah, Padang \\ Korespondensi: kornialiadrg@gmail.com
}

\begin{abstract}
ABSTRAK
Latar belakang: tekanan mekanis yang ringan pada aktivasi peranti ortodonti lepasan dapat menimbulkan respons inflamasi pada jaringan periodontal. Interleukin-1 $\beta$ merupakan salah satu sitokin inflamasi yang kadarnya meningkat dalam cairan sulkus gingiva di sekitar gigi yang bergerak. Tujuan: penelitian ini bertujuan untuk mengetahui perbedaan kadar interleukin- $1 \beta$ pada aktivasi peranti ortodonti lepasan pada waktu 0 jam, 24 jam dan 48 jam setelah aktivasi dengan pemberian tekanan mekanis. Metode: jenis penelitian ini adalah observasional analitik. Sebanyak 6 pasien yang bersedia ikut dalam penelitian diambil sebagai subjek penelitian dengan kondisi maloklusi gigi insisivus bawah yang berjejal. Pengambilan sampel dilakukan sebanyak 3 kali, yaitu: sebelum pemberian tekanan, serta 24 jam dan 48 jam setelah pemberian tekanan. Cairan sulkus gingiva diambil dengan paper point dari gigi insisivus bawah yang diberi tekanan ringan dengan klamer simpel sebesar 20-26 gr/ $\mathrm{cm}^{2}$. Sampel selanjutnya diperiksa dengan metode ELISA (Enzyme Linked Immunosorbent Assay) dengan reagen Human ELISA kit interleukin-1 $\beta$. Data yang didapat dianalisis dengan uji t-paired. Hasil: pada penelitian didapat rerata kadar interleukin- $1 \beta$ pada waktu 0 jam, 24 jam dan 48 jam adalah $0,39 \mathrm{pq} / \mathrm{ml}, 0,93 \mathrm{pq} / \mathrm{ml}$ dan $0,69 \mathrm{pq} / \mathrm{ml}$. Hasil uji statistik dengan t-paired menunjukkan tidak terdapat perbedaan kadar interleukin- $1 \beta$ yang signifikan antara 0 jam dengan 24 jam dan antara 24 jam dengan 48 jam, dengan $\mathrm{p}>0,05$. Kesimpulan: dari hasil penelitian dapat disimpulkan bahwa tekanan mekanis pada aktivasi peranti ortodonti lepasan menimbulkan respon inflamasi akut yang ditandai dengan peningkatan kadar interleukin- $1 \beta$ pada waktu 24 jam dan menurun pada waktu 48 jam.
\end{abstract}

Kata kunci: kadar interleukin-1 $\beta$, aktivasi peranti, peranti ortodonti lepasan

\section{ABSTRACT}

Background: mild mechanical pressure on the activation of removable orthodontic appliances elicits an inflammatory response in periodontal tissue. Interleukin-1 $\beta$ is an inflammatory cytokine whose level is increased in the gingival crevicular fluid around a moving tooth. Purpose: this study aims to determine differences in levels of interleukin-1 $\beta$ in the activation of removable orthodontic appliances at 0 hours, 24 hours and 48 hours after activation by applying mechanical pressure. Method: this type of research is analytic observational. A total of 6 patients who were willing to take part in the study were taken as research subjects with conditions of congested lower incisors malocclusion. Sampling was carried out 3 times, 0 hours before applying pressure, 24 hours and 48 hours after applying pressure. Gingival sulcus fluid is taken with a paper point on the lower incisors which is applied lightly to a simple clamary of $20-26 \mathrm{~g} / \mathrm{cm}^{2}$. Subsequent samples were examined by the ELISA (Enzyme Linked Immunosorbent Assay) method with the Human ELISA reagent kit interleukin-1 $\beta$. The data obtained were analyzed by paired t-test. Result: the results of the study showed the average levels of interleukin- $1 \beta$ at 0 hours, 24 hours and 48 hours were $0.39 \mathrm{pq} / \mathrm{ml}, 0.93 \mathrm{pq} / \mathrm{ml}$ and $0.69 \mathrm{pq} / \mathrm{ml}$. Statistical test with paired t-test there was no significant difference in interleukin-1 $\beta$ levels between 0 hours to 24 hours and between 24 hours to 48 hours, with $p>0.05$. Conclusion: from the results of the study it can be concluded that mechanical pressure on the activation of removable orthodontic devices induces an acute inflammatory response characterized by an increase in interleukin-1 $\beta$ levels at 24 hours and decreases at 48 hours.

Keywords: Interleukin-1ß levels, Appliances activation, Removable orthodontic appliances

\section{LATAR BELAKANG}

$\mathrm{K}$

ebutuhan akan perawatan ortodonti pada masa kini semakin meningkat. Terlihat dengan meningkatnya perawatan ortodonti dengan memakai peranti ortodonti, baik peranti cekat maupun lepasan. Peranti ortodonti lepasan masih banyak dipakai, terutama di negara yang sedang berkembang. ${ }^{1}$ Peranti ortodonti lepasan mempunyai beberapa keuntungan dan 
keterbatasan bila dibandingkan dengan peranti cekat. Beberapa keuntungan pemakaian peranti ortodonti lepasan adalah peranti bisa dilepas oleh pasien sehingga mudah dibersihkan, kebersihan dan kesehatan geligi dan struktur rongga mulut juga bisa dipertahankan selama terapi, sulit untuk mengaplikasikan tekanan yang besar serta konstruksi peranti lepasan sebagian besar dilakukan di laboratorium dan hanya membutuhkan sedikit waktu di klinik. ${ }^{2}$

Pertimbangan pemilihan antara pemakaian peranti ortodonti cekat dengan peranti lepasan dalam perawatan ortodonti terutama tergantung pada gerakan gigi yang akan dihasilkan. ${ }^{3}$ Peranti lepasan terutama menghasilkan gerakan gigi dengan cara tipping. Untuk menghasilkan gerakan rotasi, bodily dan apikal (torque) secara efisien maka diperlukan peranti cekat. ${ }^{4}$

Pergerakan gigi adalah basis dari perawatan ortodonti, sehingga untuk dapat melakukan perawatan tersebut maka harus terjadi pergerakan gigi untuk mengembalikan posisi gigi yang menyimpang ke posisi yang baik sesuai dengan oklusinya. ${ }^{3}$ Pergerakan gigi secara ortodonti terjadi karena tekanan mekanis yang diberikan pada alat ortodonti yang bertujuan untuk menggerakkan gigi. Proffit (2007) mengatakan tekanan yang ringan dan kontinu akan menghasilkan pergerakan gigi yang lebih efisien, sedangkan tekanan yang besar harus dihindari karena akan menimbulkan perubahan pada jaringan periodontal dan tulang alveolar. ${ }^{5}$ Pada tulang alveolar akan terjadi respon biologis jaringan periodontal berupa remodeling tulang karena proses resorbsi dan aposisi tulang alveolar yang menyebabkan gigi bergerak. ${ }^{6}$

Oppenheim dan Schwarz (2004) menyatakan bahwa tekanan ortodonti optimum hendaknya selaras dengan tekanan pembuluh darah kapiler yaitu 20-26 gram $/ \mathrm{cm}^{2}$ permukaan akar gigi. Secara klinis, tekanan ortodonti optimum memiliki karakteristik sebagai berikut yaitu menghasilkan pergerakan gigi yang relatif cepat, dengan sedikit ketidaknyamanan pada pasien, serta mobilitas gigi yang tidak menonjol. ${ }^{7}$

Tekanan mekanis dari peranti ortodonti merangsang respon inflamasi aseptik. Selama tahap awal pergerakan gigi terjadi peningkatan permeabilitas vaskular dan infiltrasi leukosit. ${ }^{8}$ Tekanan mekanis ini dianggap menginduksi sel-sel dalam periodonsium untuk membentuk zat biologis aktif, seperti sitokin dan enzim, yang bertanggung jawab untuk renovasi jaringan ikat. Zat ini dapat dipantau secara non-invasif pada manusia dengan mengikuti perubahan dalam komposisi cairan sulkus gingiva selama pergerakan gigi ortodonti. ${ }^{9}$ Konsentrasi yang tinggi dari sitokin inflamasi seperti interleukin-1 (IL-1), IL-2, IL-3, IL-6, IL-8, tumor necrosis factor $-\alpha$ (TNF- $\alpha$ ), interferon- $\gamma$ (IFN- $\gamma$ ) dan faktor diferensiasi osteoklas telah ditemukan dalam cairan sulkus gingiva di sekitar gigi yang bergerak. ${ }^{8}$

Dalam cairan sulkus gingiva lebih dari 100 protein terdeteksi, salah satunya adalah sitokin. ${ }^{9}$
Mekanisme resorbsi tulang yang berhubungan dengan mediator inflamasi adalah sitokin proinflamasi yaitu IL-1. Interleukin-1 terdiri atas interleukin- $1 \alpha$ (IL-1 $\alpha$ ), interleukin-1 $\beta$ (IL-1 $\beta$ ) dan interleukin-1 reseptor antagonis (IL-1ra) yang merupakan sitokin antiinflamasi. Interleukin-1 $\beta$ lebih berperan terhadap metabolisme tulang dan jika terdapat stress mekanis maka produksi interleukin-1 $\beta$ akan meningkat dan berdifusi ke dalam cairan sulkus gingiva. ${ }^{10,11}$

Penelitian tentang pergerakan gigi dimulai kurang lebih seratus tahun yang lalu, dilihat dari aspek seluler, histologis, radiologis dan yang terbaru adalah biologi molekuler dan genetika. Profil dari bermacammacam sitokin, faktor pertumbuhan, gen dan enzim-enzim yang dihubungkan dengan pergerakan gigi ortodonti telah banyak diteliti dan biasanya pengambilan sampelnya dari cairan sulkus gingiva.

Penelitian yang dilakukan Yamaguchi dkk (2006) menemukan bahwa interleukin-1 $\beta$ dalam cairan sulkus gingiva meningkat seiring dengan pergerakan gigi ortodonti, yang menunjukkan adanya inflamasi sebagai respons terhadap tekanan mekanis. Kadar interleukin-1 $\beta$ dalam cairan sulkus gingiva gigi yang dirawat lebih tinggi secara signifikan $(\mathrm{P}<0,001)$ dibandingkan gigi kontrol mulai dari 8 sampai 72 jam, dan mencapai puncak setelah 24 jam. ${ }^{12}$

Penelitian yang dilakukan oleh Kaya dkk, (2010) selama 7 hari pada pasien perawatan ortodonti dengan pencabutan gigi premolar atas, didapatkan hasil bahwa rata-rata nilai interleukin-1 $\beta$ sebelum pemberian gaya ortodonti adalah $31,22 \mathrm{pg} / \mathrm{ml}$, dan mencapai puncak pada 24 jam yaitu $91,3 \mathrm{pg} / \mathrm{ml}$ kemudian menurun setelahnya. ${ }^{13}$ Sedangkan menurut Iwasaki dkk (2001) pada penelitiannya menyatakan bahwa terdapat peningkatan jumlah interleukin-1 $\beta$ selama 28 hari ketika gaya ortodonti diaplikasikan. ${ }^{14}$ Tzannetou dkk, (2008) menyatakan bahwa terdapat peningkatan interleukin-1 $\beta$ yang mencapai puncaknya pada 24 jam setelah ekspansi rahang atas dengan menggunakan rapid palatal expansion. ${ }^{15}$

Berdasarkan latar belakang di atas peneliti ingin mengetahui kadar interleukin- $1 \beta$ pada aktivasi peranti ortodonti lepasan. Tujuan penelitian ini adalah untuk mengetahui perbedaan kadar interleukin-1 $\beta$ pada peranti ortodonti lepasan pada waktu 0 jam, 24 jam dan 48 jam setelah pemberian tekanan mekanis.

\section{METODE PENELITIAN}

Jenis penelitian ini adalah observasional analitik. Sampel penelitian adalah bagian dari populasi yang dipilih dengan cara tertentu dan dianggap dapat mewakili populasi dengan memenuhi kriteria inklusi dan eksklusi. Kriteria inklusi adalah pasien laki-laki dan perempuan usia 19 sampai 25 tahun yang bersedia ikut dalam penelitian, kondisi maloklusi gigi insisivus bawah yang berjejal dengan rahang atas berjejal atau tidak dan kondisi jaringan periodontal sehat. Sedangkan kriteria 
eksklusi adalah subjek mengkonsumsi antibiotik dan antiinflamasi selama 6 bulan terakhir dan menstruasi.

Sampel diambil dengan teknik non probability sampling, yaitu consecutive sampling, dimana semua subjek yang datang ke secara berurutan dan memenuhi kriteria inklusi dimasukkan ke dalam penelitian sampai jumlah subjek yang diperlukan terpenuhi. ${ }^{16}$ Pemeriksaan sampel dilakukan di Laboratorium Biomedik Fakultas Kedokteran Universitas Andalas. Lama penelitian sekitar \pm 5 bulan.

Sebelum pengambilan sampel cairan sulkus gingiva: dilakukan persiapan dengan melarutkan 1 tablet PBS dalam $100 \mathrm{ml}$ aquades, kemudian $200 \mu \mathrm{l}$ larutan PBS dipindahkan ke dalam tube eppendorf. Tube dimasukkan ke dalam cooler box yang sudah berisi es batu. Pengambilan sampel dilakukan 3 waktu, yaitu 0 jam sebelum pemberian tekanan, 24 jam sesudah pemberian tekanan yaitu pada saat puncak kadar interleukin- $1 \beta$ pada penelitian sebelumnya, ${ }^{13,15}$ dan 48 jam (2 hari) setelah pemberian tekanan yaitu pada saat terjadinya resorpsi frontal. ${ }^{17}$ Pada gigi insisivus bawah yang diberi tekanan ringan dengan klamer simpel sebesar 20-26 gr/ $\mathrm{cm}^{2}$, sampel diambil dengan paper point pada daerah tekanan dan pada sisi vestibular untuk mencegah kontaminasi saliva, sebelumnya sisi pengambilan sampel diisolasi dengan cotton roll, plak dihilangkan dan permukaan gigi dikeringkan. Paper point dimasukkan ke dalam sulkus sedalam $1 \mathrm{~mm}$ selama 30 detik untuk mengambil cairan sulkus. Sampel dengan kontaminasi saliva dan darah dieksklusikan. Cairan sulkus gingiva pada paper point dimasukkan ke dalam tube eppendorf $2 \mathrm{ml}$ berisi PBS $200 \mu \mathrm{l}$ dan disimpan dalam suhu $-80^{\circ} \mathrm{C}$ dan selanjutnya diperiksa dengan metode ELISA (Enzyme Linked Immunosorbent Assay) dengan reagen Human ELISA kit interleukin-1 $\beta$. Data yang didapat dianalisis dengan one way anova.

\section{HASIL PENELITIAN}

Penelitian untuk mengetahui kadar interleukin$1 \beta$ pada pemakai peranti ortodonti lepasan telah dilakukan pada bulan agustus 2013. Enam orang pasien berusia 19 tahun sampai 24 tahun yang memakai peranti ortodonti lepasan diambil sebagai subjek penelitian, dimana pengambilan sampel dilakukan dalam 3 waktu yaitu 0 jam, 24 jam dan 48 jam setelah aktivasi dengan pemberian tekanan mekanis. Lalu kadarnya diukur dengan metode ELISA.

Tabel 1. Rerata kadar interleukin- $1 \beta$ peranti ortodonti lepasan pada 0 jam, 24 jam dan 48 jam

\begin{tabular}{ccc}
\hline Peranti lepasan & N & Mean \\
\hline Kadar 0 jam & 6 & 0,39 \\
Kadar 24 jam & 6 & 0,93 \\
Kadar 48 jam & 6 & 0,69 \\
\hline
\end{tabular}

Satuan $\mathrm{pg} / \mathrm{ml}$
Rerata kadar interleukin-1 $\beta$ peranti ortodonti lepasan dapat dilihat pada tabel 1 , kadar interleukin-1 $\beta$ meningkat pada waktu 24 jam setelah aktivasi.

Tabel 2. Perbedaan kadar interleukin- $1 \beta$ peranti lepasan antara waktu 0 jam dan 24 jam

\begin{tabular}{cccccc}
\hline Variabel & n & Rerata & SD & SE & p value \\
\hline 0 jam & 6 & 0,39 & 0,47 & 0,19 & 0,27 \\
24 jam & 6 & 0,93 & 0,79 & 0,32 & \\
\hline
\end{tabular}

$\mathrm{p}>0,05$, tidak terdapat perbedaan signifikan Satuan $\mathrm{pg} / \mathrm{ml}$

Pada tabel 2 terlihat tidak ada perbedaan yang signifikan antara kadar interleukin- $1 \beta$ sebelum aktivasi ( 0 jam) dengan 24 jam setelah aktivasi dimana $\mathrm{p}>0,05$.

Tabel 3. Perbedaan kadar interleukin $-1 \beta$ peranti lepasan antara waktu 24 jam dan 48 jam

\begin{tabular}{cccccc}
\hline Variabel & $\mathbf{n}$ & Rerata & SD & SE & p value \\
\hline $\mathbf{2 4}$ jam & 6 & 0,93 & 0,79 & 0,32 & ----- \\
$\mathbf{4 8}$ jam & 6 & 0,63 & 0,63 & 0,26 & \\
\hline
\end{tabular}

$\mathrm{p}>0,05$, tidak terdapat perbedaan signifikan Satuan $\mathrm{pg} / \mathrm{ml}$

Pada tabel 3 juga tidak terdapat perbedaan yang signifikan antara kadar interleukin-1 $\beta 24$ jam dengan 48 jam setelah aktivasi dimana $\mathrm{p}>0,05$.

\section{PEMBAHASAN}

Perawatan ortodonti direkomendasikan untuk perbaikan fungsi dan estetis. Pasien melakukan perawatan ortodonti terutama untuk alasan estetis, sedangkan ortodontis secara khusus merekomendasikan perawatan ortodonti kepada pasien untuk memperbaiki fungsi. Perawatan ortodonti dapat dilakukan dengan menggunakan peranti lepasan atau cekat. Peranti lepasan memiliki plat akrilik dengan clasp dan spring dengan berbagai posisi tergantung pada kebutuhan perawatan. Kasus ortodonti sederhana dapat dirawat dengan menggunakan peranti lepasan. Pada peranti lepasan, pasien yang tidak mematuhi dan tidak rajin menggunakan peranti ini akan memperpanjang masa perawatan, dan menyebabkan perawatan yang lambat atau bahkan terjadi relaps. Sedangkan peranti cekat digunakan pada kebanyakan kasus ortodonti. ${ }^{18}$

Pergerakan gigi pada dasarnya melalui tiga tahap, yaitu: tahap perubahan aliran pembuluh darah yang berhubungan dengan adanya tekanan pada ligamen periodontal, tahap pembentukan dan pelepasan pembawa pesan kimia serta tahap aktivasi sel. Tekanan pada ligamen periodontal menyebabkan aliran darah berkurang pada sisi tekanan dan akan bertambah 
pada sisi regangan sehingga terjadi peningkatan permeabilitas vaskular dan infiltrasi leukosit., ${ }^{8,10}$

Peranti ortodonti mengandalkan tarikan statis yang menimbulkan remodeling tulang dan pergerakan gigi. Tekanan mekanis pada gigi menghasilan pergerakan mikro berupa resorbsi dan aposisi tulang pada bagian akar sehingga kombinasi ini menghasilkan proses remodeling tulang selama perawatan. ${ }^{18}$

Pergerakan gigi secara ortodonti terjadi melalui remodeling tulang alveolar akibat tekanan yang berlebihan pada jaringan periodontal. Hialinisasi akan terjadi pada daerah tekanan jika tekanan lebih besar dari tekanan pembuluh darah sehingga terjadi daerah nekrosis karena osteoklas yang berasal dari jaringan yang mengalami lesi. Pada daerah yang berlawanan yaitu daerah regangan osteoblas akan menyebabkan proses aposisi tulang. ${ }^{13}$

Sel osteoklas yang terlibat dalam resorbsi tulang adalah multinucleated giant cell yang berasal dari stem cell hemapoetik. Sitokin proinflamasi memegang peranan penting dalam resorbsi tulang dan akar serta merupakan penenda resorbsi tulang awal yang ditandai oleh interleukin- $1 \beta$. Interleukin- $1 \beta$ akan mempengaruhi mekanisme tulang secara langsung. Pada konsentrasi yang sangat rendah IL-1 $\beta$ berperan pada proses remodeling tulang melalui reseptor spesifik pada sel-sel tulang. Secara tidak langsung monosit dan makrofag menghasilkan interleukin$1 \beta$ melalui pelepasan sitokin. Aktivitas protein osteoklastik dilakukan melalui aktivasi faktor kappa $B$ (RANK) dan faktor nuklir kappa ligand (RANKL). Sel osteoblas juga mengendalikan osteoklas dengan mensintesa RANKL untuk memicu diferensiasi osteoklas yang lebih banyak. ${ }^{13,19}$

Penelitian ini dilakukan untuk mengetahui kadar interleukin-1 $\beta$ pemakaian peranti ortodonti lepasan pada waktu 0 jam, 24 jam dan 48 jam setelah pemberian tekanan mekanis. Penelitian mengenai pergerakan gigi dapat dilihat dari beberapa aspek, yaitu klinis, seluler dan biomekanis. Penelitian secara seluler akan memberikan gambaran kondisi jaringan biologis selama pergerakan gigi.

Pasien peranti lepasan memakai kawat stainless steel 0,6 mm sebagai komponen kekuatan untuk menggerakan gigi dan kawat 0,7 mm untuk klamer retensi. Pengukuran kadar interleukin-1 $\beta$ dilakukan sebanyak tiga waktu, yaitu pemeriksaan 0 jam sebelum pemberian tekanan adalah sebagai nilai kontrol, 24 jam setelah pemberian tekanan mekanis saat diperkirakan kadar interleukin-1 $\beta$ akan mencapai puncak dan 48 jam untuk melihat penurunan kadar dari interleukin-1 $\beta$.

Sulkus gingiva dipilih sebagai daerah pemeriksaan karena berhubungan langsung dengan ligamen periodontal dan akses yang mudah di dalam rongga mulut. Tekanan pada ligamen periodontal akan menyebabkan migrasi produk biokimia ke dalam sulkus gingiva. Hal yang sulit dalam mendapatkan cairan sulkus gingiva adalah karena jumlahnya yang terbatas. Pada beberapa penelitian sebelumnya, pengambilan cairan sulkus gingiva dengan menggunakan paper strip. Namun karena kesulitan untuk mendapatkan paper strip, maka peneliti menggunakan paper point untuk mendapatkan cairan sulkus gingiva. Penelitian terdahulu untuk mendapatkan sampel cairan sulkus gingiva juga pernah dilakukan oleh Kusumadewy (2012) dan Indriyanti (2007). Pengambilan cairan sulkus gingiva diambil dengan metode intrasulkuler dengan memasukkan paper point ke dalam sulkus selama 30 detik. $^{10,20}$

Gigi insisivus bawah diambil cairan sulkusnya pada bagian vestibular karena gigi ini sering berjejal, mudah diamati dan dibersihkan. Pengambilan cairan sulkus diambil sebanyak satu kali pengambilan pada daerah tekanan. Daerah tekanan adalah daerah yang mengalami tekanan oleh peranti ortodonti yang searah dengan arah pergerakan gigi.

Konsentrasi interleukin-1 $\beta$ dengan satuan pg/ $\mathrm{ml}$ didapatkan dengan mengambil sampel cairan sulkus gingiva pada sulkus gingiva. Sebelum konsentrasi interleukin-1 $\beta$ diukur dengan metode ELISA, paper point yang berisi sampel cairan sulkus gingiva diencerkan dengan $200 \mu$ l larutan PBS (Phosphate Buffered Saline) yang dimasukkan ke dalam tube eppendorf $2 \mathrm{ml}$. Kesehatan jaringan periodontal dilihat dengan melakukan probing ke dalam sulkus gingiva dan tidak ada tanda-tanda inflamasi secara umum, namun tanpa melakukan perhitungan dengan memakai indeks periodontal.

Pada hasil pemeriksaan kadar interleukin$1 \beta$ terdapat nilai-nilai ekstrim dan nilai yang tidak terbaca sehingga terpaksa dieksklusikan dan akhirnya didapatkan 6 sampel. Nilai ekstrim yang didapat kemungkinan disebabkan karena sudah terdapat inflamasi sebelum peranti dipasang walaupun secara visual tidak terdapat tanda-tanda inflamasi dan perdarahan pada probing. Sampel yang tidak terbaca kemungkinan disebabkan karena larutan standar yang dipakai pada kurva standar konsentrasinya terlalu rendah.

Peranti lepasan tekanannya bersifat intermittent, yaitu tekanan ortodonti aktif yang besarnya dapat berkurang sampai dengan nol diantara dua waktu kunjungan perawatan. Tekanan intermittent ini mencapai nol ketika alat dilepas dan kembali pada besar tekanan semula ketika alat dipasang kembali dalam mulut. ${ }^{5,721}$ Tipe gerakan yang sering dihasilkan peranti lepasan adalah gerak tipping yang membutuhkan kekuatan tekanan 35 gr pada gigi insisivus. ${ }^{17}$

Pemakaian peranti lepasan ini memiliki pola konsentrasi interleukin-1 $\beta$ yang meningkat pada 24 jam setelah aplikasi tekanan kemudian menurun setelah 48 jam. Hal ini sesuai dengan penelitian yang dilakukan Yamaguchi dkk (2006), Kaya dkk (2010) 
dan Tzannetou dkk (2008), dimana kadar interleukin$1 \beta$ mencapai puncak setelah 24 jam. ${ }^{12,13,15}$

Menggerakkan gigi secara ortodontis diperlukan kekuatan yang bisa bertahan dalam waktu yang lama dan tidak mesti berkesinambungan (continuous). Kekuatan tersebut harus tetap ada beberapa jam per hari minimal 4 jam per hari untuk dapat menimbulkan reaksi seluler pada ligamen periodontal. Secara klinis ambang waktu lamanya kekuatan adalah 4-8 jam sehingga kekuatan yang berlangsung lebih lama akan menghasilkan gerakan yang lebih efektif.

Tekanan yang diberikan pada gigi menimbulkan perubahan pada ligamen periodontal. Pada tekanan yang ringan maka beberapa detik setelah pemberian tekanan akan keluar cairan pada ligamen periodontal dan gigi bergeser pada ligamen, selanjutnya pembuluh darah pada ligamen akan tertekan pada sisi tekanan dan melebar pada sisi tarikan, serat periodontal dan bentuk sel berubah. Pada waktu kurang dari 4 jam perubahan metabolik dan kimia akan mempengaruhi aktivitas sel dan perubahan level enzim. Pada waktu 2 hari (48 jam) osteoblas dan osteoklas akan mengubah bentuk soket sehingga gigi mulai bergerak. Pada tekanan yang besar maka dalam waktu 2-5 detik pembuluh darah akan menutup pada sisi tekanan sehingga dalam beberapa jam sel-sel di daerah tersebut akan mati dan dalam 3-5 hari terjadi undermining resorption akibat diferensiasi sel yang berdekatan dengan sumsum tulang dan akhirnya pada 7-14 hari gigi baru mulai bergerak. ${ }^{5}$

Pemberian tekanan dari peranti lepasan adalah tekanan yang ringan sehingga terjadi peningkatan kadar interleukin-1 $\beta$ pada waktu 24 jam dan menurun pada waktu 48 jam. Pada waktu 48 jam (2 hari) setelah pemberian tekanan mekanis dari peranti terjadi pergerakan gigi akibatnya kadar interleukin-1 $\beta$ menurun.

Pergerakan gigi terdiri dari 3 fase, yaitu: fase inisial, fase lambat dan fase postlag. Fase inisial ditandai dengan pergerakan yang cepat dan segera dan terjadi antara 24 jam hingga 48 jam setelah pemasangan peranti pertama. Fase ini memiliki kecepatan yang besar yang dihubungkan dengan pergerakan gigi pada ruang ligamen periodontal. Fase lambat terjadi antara 20 sampai 30 hari dan menunjukkan pergerakan gigi yang relatif kecil. Fase ini ditandai dengan hialinisasi ligamen periodontal pada daerah tekanan. Pada fase ini tidak ada pergerakan gigi sampai sel selesai menghilangkan seluruh jaringan nekrotik. Fase postlag mengikuti fase lambat, dimana terjadi peningkatan gerakan. ${ }^{19}$

Penelitian yang dilakukan Yamaguchi dkk (2006) interleukin-1 $\beta$ dalam cairan sulkus gingiva meningkat seiring dengan pergerakan gigi ortodonti, dan menunjukkan bahwa peningkatan seperti ini bisa terlibat dalam inflamasi sebagai respons terhadap tekanan mekanis. Kadar interleukin-1 $\beta$ dalam cairan sulkus gingiva untuk gigi yang dirawat secara signifikan lebih tinggi ( $\mathrm{P}<0,001)$ dibanding untuk gigi kontrol yang bersangkutan mulai dari 8 sampai
72 jam, dan mencapai puncak setelah 24 jam. ${ }^{12}$ Kaya, Hamamci, Basaran, Dogru dan Yildirim (2010) pada pasien perawatan ortodonti dengan pencabutan gigi premolar atas selama 7 hari, didapatkan hasil bahwa rata-rata nilai interleukin- $1 \beta$ sebelum pemberian gaya ortodonti adalah 31,22 pg/ml, dan mencapai puncak pada 24 jam yaitu 91,3 pg/ml kemudian menurun setelahnya ${ }^{13}$. Tzannetou, Elfratiadis, Nicolay, Grbic, dan Lamster (2008) menyatakan bahwa terdapat peningkatan interleukin-1 $\beta$, puncaknya adalah pada 24 jam setelah ekspansi rahang atas dengan menggunakan rapid palatal expansion. ${ }^{15}$ Dari penelitian-penelitian ini dapat disimpulkan bahwa kadar interleukin-1 $\beta$ terutama pada 24 jam akan meningkat dibandingkan dengan sebelum pemberian tekanan mekanis.

Pada penelitian ini terdapat beberapa keterbatasan, diantaranya adalah jumlah sampel yang sedikit, sampel tidak homogen, waktu penelitian yang singkat dan adanya variasi individu serta kompleksitas dalam melakukan penelitian in vivo. Selain itu juga terdapat banyak faktor yang mempengaruhi pergerakan gigi serta mekanoterapi dan kondisi biologis.

\section{KESIMPULAN DAN SARAN}

Dari hasil penelitian dapat disimpulkan bahwa tekanan mekanis pada aktivasi peranti ortodonti lepasan menimbulkan respon inflamasi akut yang ditandai dengan peningkatan kadar interleukin-1 $\beta$ pada waktu 24 jam dan menurun pada waktu 48 jam setelah aktivasi.

Penelitian selanjutnya disarankan untuk menggunakan sampel yang lebih banyak dan variasi yang lebih homogen misalnya dengan jenis kelamin yang sama, serta pengambilan sampel cairan sulkus gingiva pada daerah tekanan dan regangan.

\section{DAFTAR PUSTAKA}

1. Susilowati, Mudjari I. Dinamika Ekspresi Gen Matrix Metalloproteinase-8 dan Tissue Inhibitor Metalloproteinase-1 Pada Pemakai Peranti Ortodonti Lepasan. 2011. http://repository.unhas.ac.id/ handle/123456789/606.

2. Foster TD. Buku Ajar Ortodonti (A Textbook of Orthodontics). $3^{\text {rd }}$ ed. Jakarta: EGC, 1997: 168-183, 240252.

3. Bahirrah S. Pergerakan Gigi Dalam Bidang Ortodonsia Dengan alat Cekat. FKG USU. 2004. http://repository. usu.ac.id/bitstream/123456789/1164/1.

4. Isaacson KG, William JK. Pengantar Fixed Appliances (An Introduction To Fixed Appliances). Alih Bahasa; drg. Budi susetyo.Jakarta: Binarupa aksara, 1992: 7-15.

5. Proffit WR, Fields HW, Ackerman JL, Thomas PM, Tulloch JFC. Contemporary Orthodontics. St. Louis, Toronto, London: CV Mosby Company,1986: 228-245

6. Apajalahti S, Sorsa $\mathrm{T}$, Railavo $\mathrm{S}$, Ingman $\mathrm{T}$. The invivo levels of matrix metalloproteinase- 1 and -8 in gingival crevicular fluid during initial orthodontic tooth movement.Journal of dental Research. 2003; 82(12):1018-1022. 
7. Anggani HS. Pengaruh Tekanan Ortodonti Pada Perubahan Mikrostruktur Permukaan Jaringan Sementum. Disertasi. FKG UI.2012.

8. Teixeira CC, Khoo E, Tran J, Chartres I, Liu Y, Thant LM, Khabensky I, Gart LP, Cisneros G, Alikhani M. Cytokines Expression And Accelerated Tooth Movement. J Dent Res.2010; 89(10):1135-1141.

9. Shetty SK, Kumar M, Smitha PL. Cytokines and Orthodontic Tooth Movement. Journal of Dental Sciences and Research. 2011; 2(1):132-141.

10. Kusumadewy W. Perbandingan Kadar Interleukin-1 $\beta$ (IL-1 $\beta$ ) Dalam Cairan Krevikular Gingiva Anterior Mandibula Pasien Pada Tahap Awal Perawatan Ortodonti Menggunakan Braket Self-Ligating Pasif Dengan Braket Konvensional Pre-Adjusted MBT. Tesis. Jakarta: FKG UI. 2012.

11. Dinarello CA. Interleukin-1, Interleukin-receptors And Interleukin-1 receptor antagonist. Int Rev Immunol. 1998; 16(5-6):457-99.

12. Yamaguchi M, Yoshii M, Kasai K. Relationship Between Substance P and Interleukin-1 $\beta$ in Gingival Crevicular Fluid During Orthodontic Tooth Movement in Adult. The European Journal of Orthodontics.2006; 28(3): 241-6.

13. Kaya FA, Hamamci N, Basaran G, Dogru M, Yildirim TT. TNF- $\alpha$, IL- $1 \beta$ and IL-8 Levels in Tooth Early Levelling Movement Orthodontic Treatment. J Int Dent Med Res.2010;3(3): 116-121.
14. Iwasaki LR, Haack JE, Nickel JC, Reinhardt RA, Petro TM. Human Interleukin-1beta and Interleukin-1 Receptor Antagonist Secretion and Velocity of Tooth Movement. Arc Oral Biol.2001;46(2):185-9.

15. Tzannetou S, Efstratiadis S, Nicolay O, Grbic J, Lamster I. Comparison of Level of Inflammatory Mediators IL-1beta and BetaG in Gingival Crevicular Fluid from Molars, Premolars, and Incisors During Rapid Palatal Expansion. Am J Orthod Dentofacial Orthop.2008;133(5):699-707.

16. Sastroasmoro S, Ismael S. Dasar-dasar Metodologi Penelitian Klinis. Edisi ke-4,. Jakarta: Sagung Seto, 2011: 99.

17. Mao JJ,Kan CH. 2013. Advances In Orthodontics Treatment http://acceledent.com/images/uploads/4Ai-Continuing-Education-Peer-Reviewed-Advances-inOrtho-Treatment1.pdf. Diakses 12 Maret 2013 22:22.

18. Arifin SHZ, Yamamoto Z, Abidin IZZ, Wahab RMA, Arifin ZZ. Cellular and Molecular Changes in Orthodontic Tooth movement. Scientific World Journal. 2011; 11: 1788-1803.

19. Indriyanti R. Kadar Interleukin 1 beta Pada Cairan Celah Gusi (CCG) Sebagai Penanda Inflamasi Setelah Pemasangan Mahkota Baja Nikarat Pada Gigi Sulung Posterior. In Bandung: FKG UNPAD.2007

20. Rahardjo P. Ortodonti Dasar. Airlangga University Press. Surabaya. 2009: 60-153.

21. Graber TM. Orthodontics. $3^{\text {rd }}$ ed. St. Louis, Missouri: Mosby Inc,1994: 140-145. 